\title{
Analisis Teknik Permainan Biola pada Voorspell Keroncong Senyuman Candra
}

\author{
Pipin Garibaldi ${ }^{1}$, Pandu Hapsara ${ }^{2}$ \\ ${ }^{1}$ Prodi Musik, FSP, ISI Yogyakarta, Jl. Parangtritis Km 6.5 Panggungharjo, Sewon, Bantul \\ 2 Alumnus Program Studi S-1 Seni Musik, FSP ISI Yogyakarta \\ 1pipingaribaldi@gmail.com, ${ }^{2}$ panduhapsara@gmail.com
}

\begin{abstract}
Abstrak
Voorspell pada musik keroncong memiliki karakteristik tersendiri. Artikel ini bertujuan menelaah voorspell keroncong asli yaitu bagian pembuka suatu lagu berupa improvisasi biola khas musik keroncong. Kajian ini berfokus pada lagu Senyuman Candra karya W.S Nardi yang digubah Budiman BJ. Voorspell yang terdapat pada lagu ini menggunakan skala pentatonis pelog. Ini tidaklah lazim karena teknik voorspell umumnya mengacu pada progresi akor I - IV - V - I. Metode yang digunakan yaitu metode kualitatif dengan pendekatan deskriptif analisis. Tahapan penelitian meliputi kajian pustaka yakni kajian literatur musik keroncong serta analisis bentuk dan gaya musik. Penelitian lapangan dilakukan melalui wawancara beberapa pelaku musik keroncong, meliputi pelaku yang mempunyai latar belakang akademisi serta pelaku yang memang seorang praktisi musik keroncong. Hasil penelitian menunjukkan bahwa voorspell pada lagu Senyuman Candra menghadirkan karakter dan ciri khas Budiman BJ.
\end{abstract}

Kata kunci: biola, voorspell, keroncong

\begin{abstract}
Voorspell in keroncong music has its own characteristics. This article aims to examine the voorspell of Keroncong Asli, which is the opening part of a song in the form of an improvised violin typical of keroncong music. This study focuses on the song Senyuman Candra by W.S Nardi arranged by Budiman BJ. The Voorspell in this song uses the Pelog pentatonic scale. This is not uncommon because the Voorspell technique generally refers to $I-I V-V$ - I chord progressions. The method used is a qualitative method with a descriptive analysis approach. The research stages include literature review, namely keroncong music literature review and analysis of musical forms and styles. Field research was carried out through interviews of several keroncong music actors, including actors who have academic backgrounds as well as actors who are indeed keroncong music practitioners. The results showed that the voorspell in the Senyuman Candra song presented the character and characteristics of Budiman $B J$.
\end{abstract}

Keywords: violin, voorspell, keroncong

\section{Pendahuluan}

Keroncong adalah musik asli nusantara yang mengalami pasang surut dan keberadaannya dapat dinyatakan timbul tenggelam, meskipun keroncong sudah terbilang musik lawas namun kehadirannya masih diminati dan dicintai hingga saat ini. Umumnya musik keroncong menggunakan isntrumen seperti biola, flute, gitar, cuk, cak, cello, bass. Terdapat kendala dalam pembelajaran musik keroncong terutama bagian voorspell untuk solo instrumen biola. Voorspell adalah introduksi dalam lagu keroncong asli, dimana permainan voorspell merupakan ajang unjuk kebolehan dan unjuk keahlian para pemain depan dalam suatu kelompok musik Keroncong. Pemain depan adalah sebutan untuk musisi yang bertugas membawakan melodi dalam musik Keroncong, umumnya pemain biola dan pemain flute. Biola 


\section{Jurnal Etnomusikologi}

dan flute mempunyai fungsi sebagai instrumen yang memainkan alur-alur melodi dan sebagai instrumen yang membawa nuansa keroncong semakin nyata. Peran pemain depan juga sebagai pembuka lagu atau voorspell. Selain oleh pemain depan, voorspell juga dapat dimainkan oleh instrumen gitar. Voorspell merupakan improvisasi yang mengacu pada akor I dan V yang diakhiri dengan overgang atau kadens lengkap, yaitu akor I - IV - V - I.

Lagu Keroncong Senyuman Candra merupakan kategori lagu Keroncong Asli, dimana lagu ini memiliki 28 birama dan diawali dengan permainan Voorspell oleh pemain biola. Lagu Keroncong Senyuman Candra di tulis oleh W.S Nardi, W.S Nardi lahir di Surakarta 25 Februari 1930, memiliki nama asli Wisnu Sunardi, namun lebih akrab di kalangan musik keroncong dengan sebutan W.S Nardi. Selain Keroncong Senyuman Candra, W.S Nardi juga menulis beberapa lagu keroncong seperti Keroncong Rapsodhi, Keroncong Cerita Malam, Keroncong Cintaku Bersemi, dan Keroncong Harapanku. Dalam proses penulisan lagu, W.S Nardi cenderung hanya menulis liriknya, dan melodinya dibuat oleh Sapari, sahabat W.S Nardi yang juga seorang seniman keroncong Surakarta.

Budiman adalah pimpinan dari Orkes Keroncong Bintang Jakarta, dan sejak 1979 telah memulai membina Keroncong Remaja di Direktorat Kesenian Jakarta. Budiman dilahirkan pada 19 Februari 1939 di kota Semarang dari keluarga seniman keroncong.
Ayahnya bernama Jaiman seorang pemain biola dan mantan anggota perkumpulan keroncong S.O.V L.A.S.O di tahun tigapuluhan.

Pada tahun 1950, Budiman sudah berani bermain keroncong di atas panggung dengan rekan-rekannya yang sebaya, yang pada waktu itu bergabung dengan Orkes Keroncong Panglipor Hati pimpinan bapak Jaiman sebagai pemain biola, Selain karirnya sebagai pemain biola keroncong dan pimpinan Orkes Keroncong Bintang Jakarta, Budiman juga lihai dalam menulis lagu, beberapa karyanya sebagai berikut: Keroncong Segenggam Harapan, Keroncong Bahana Pancasila, dan Keroncong Hanya Satu.

Voorspell berasal dari bahasa Belanda yang dalam bahasa Indonesia artinya permainan di depan, voor berarti depan dan spell berarti permainan namun kalangan musisi keroncong menyebutnya dengan prospel. Belum ada sumber yang menjelaskan awal mula penggunaan istilah Voorspell dalam musik keroncong, namun bisa jadi berasal dari bahasa belanda yang dibawa oleh bangsa Belanda yang pada saat itu menduduki wilayah Indonesia dan digunakan sampai sekarang. Sebab bila ditinjau dari musik keroncong, Voorspell selalu berada pada awal lagu, Voorspell sebagai introduksi sebuah lagu Keroncong Asli, dan bisa dikatakan bahwa Voorspell adalah permainan depan pada Musik Keroncong. Sehingga bisa disimpulkan bahwa istilah Voorspell adalah bahasa belanda yang digunakan 
oleh pelaku-pelaku musik Keroncong pada era dulu sampai sekarang. Voorspell tidak hanya berperan sebagai introduksi sebuah lagu Keroncong Asli, namun juga sebagai ajang unjuk keahlian bermain instrumen oleh pemain melodis (biola, flute, gitar). Sehingga permainan voorspell pada setiap individu pemain memiliki ciri khas masing-masing, sesuai dengan skill dan kemampuan yang dimiliki oleh pemain tersebut.

Dalam Keroncong Asli pada umumnya Voorspell dibagi menjadi tiga bagian, tiga bagian yaitu:

a. Bagian pertama solo biola diakhiri dan disambut oleh rekan-rekan pemain lain dengan bunyi serempak raal panjang dalam akor tonika.

b. Bagian kedua solo biola diakhiri dan disambut oleh rekan-rekan pemain lain dengan bunyi serempak mengejutkan dalam akor dominan septim.

c. Bagian ketiga solo biola diakhiri dan disambut oleh rekan-rekan pemain lain dalam akor tonika yang kemudian masuk dalam tempo irama keroncong (Budiman, 1979).

Adapun untuk memainkan voorspell ini, seorang pemain biola tidak diharuskan untuk memainkan semua bagian dari voorspell tersebut, jadi untuk memainkan voorsped ini sifatnya bebas, boleh dimainkan tiga bagian dan boleh juga dimainkan satu atau dua bagian saja. Untuk memainkan voorspell satu atau dua bagian saja, pemain biola itu sendiri yang akan menentukan, dan untuk ini rekan-rekan pemain lainnya hanya mengamati dan mendengarkan namun tetap memperhatikan. Mendengarkan dari melodi Voorspell yang dimainkan oleh seorang pemain biola, biasanya pemain lainnya sudah mengetahui arah kemana yang dikehendaki pemain biola tersebut. Memang dalam memainkan Voorspell ini antara pemain biola yang satu dengan pemain biola yang lain selalu tidak sama, sebab memainkan Voorspell sifatnya improvisasi (Budiman, 1979).

\section{Metode Penelitian}

Kajian ini menggunakan metode kualitatif jenis fenomenologi dengan pendekatan musikologis. Pemilihan fenomenologi berdasarkan pada tujuan penelitan yakni menggabarkan dan menjelaskan fenomena, peristiwa, aktivitas sosial, pemikiran seseorang secara individual ataupun kelompok untuk menemukan prinsip-prinsip dan pemaparan yang mengarah pada penyimpulan (Syaodih Sukmadinata, 2017). Pendekatan musikologis yang digunakan yakni pada aspek teoretikal dan analitis (Watanabe, 1967).

Pengumpulan data dilakukan melalui tahapan studi pustaka, observasi, dan penelitian lapangan sedangkan pemilihan narasumber didasari oleh kapasitas dan kualifikasi terkait musik keroncong yang meliputi praktisi musik keroncong dan akademisi musik. Langkah selanjutnya adalah analisis data menggunakan konsep deskripsi, koding verbatim dan 


\section{Jurnal Etnomusikologi}

pemaknaaan melalui refleksi dan kontruksi

(Cresswell, 2011).

\section{Hasil dan Pembahasan}

Voorspell biola pada lagu Keroncong Senyuman Candra memiliki beberapa kerumitan dalam permainannya, sehingga membutuhkan teknik bermain yang mumpuni, selain itu juga membutuhkan pemahaman musikal yang baik. Adapun analisa teknik Voorspell biola pada lagu Keroncong Senyuman Candra meliputi teknik bermain serta bagaimana menghasilkan tone (suara) yang baik sehingga dapat membawakan Voorspell biola dengan baik. Berikut analisis teknik Voorspell biola pada lagu Keroncong Senyuman Candra:

\section{Analisis Voorspell Bagian Pertama}

Dengan nada pada birama pertama, permainan mengharuskan pemain biola menggunakan posisi III, pada Voorspell bagian pertama ini secara keseluruhan pemain diharuskan menggunakan posisi III, sedangkan intensitas gesekan pada birama pertama mengharuskan pemain memainkan dengan bow penuh atau bow panjang, terutama pada nada $\mathrm{D}$.

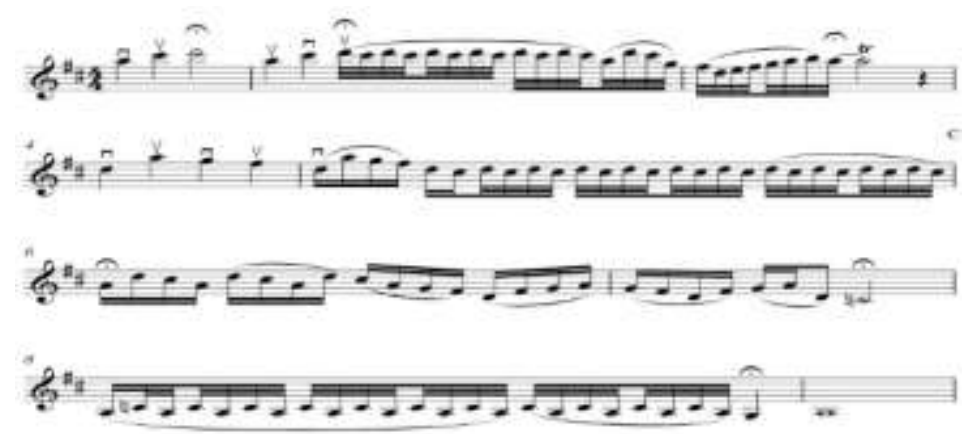

Notasi 1: Solo Biola pada Voorspell lagu Keroncong Senyuman Candra bagian pertama

Pada birama kedua, mengharuskan pemain biola cermat dalam menentukan intensitas gesekan, mengingat terdapat legato yang panjang. Pada birama ketiga tidak ada kesulitan berarti, hanya saja pada bagian trill di nada A membutuhkan kualitas suara yang baik. Pada birama empat pemain biola menunjukkan awal kalimat dengan permainan detache panjang, lalu pada birama lima motif seperenambelas diperpanjang pada nada pertama lalu dilanjutkan dengan memainkan trill menuju birama enam.Pada birama enam, pemain memperpanjang nada pertama yang kemudian dilanjutkan memainkan nada seperenambelas secara cepat dengan legato empat pada masingmasing motif, dan diakhiri gesekan panjang pada birama tujuh. Pada birama delapan hanya berisi trill nada A dan C dimainkan pada posisi I dan memperpanjang nada $G$ pada ketukan 
terakhir sebelum diakhiri dengan gesekan panjang pada nada A.

\section{Analisis Voorspell bagian kedua}

Voorspell biola pada bagian kedua merupakan bagian paling rumit, karena membutuhkan ketrampilan dan ketelitian dalam memainkannya. Pada birama sepuluh merupakan awal kalimat dimana pemain diharuskan memainkan dengan gesekan panjang dan jelas dalam posisi I, dilanjutkan pada birama sebelas merupakan permainan improvisasi yang mengacu pada tangga nada D mayor namun menghindari nada $\mathrm{E}$ dan $\mathrm{B}$, karena pada bagian ini mengacu pada modus pentatonis, permainan pada birama sebelas

Motif permainan variasi pada birama sebelas berhubungan dengan permainan pada birama dua belas, dimana pada birama dua belas pemain biola memperpanjang permainan pada nada $\mathrm{A}$ dan $\mathrm{C}$ kemudian dilanjutkan dengan

\section{Analisis Voorspell bagian ketiga}

Pada bagian ketiga birama pertama nada dimainkan dengan panjang atau long bow dalam posisi satu, kemudian dilanjutkan birama selanjutnya mengharuskan pemain mencermati legato pada motif seperenambelas dan mempercepat tempo, lalu pada motif membutuhkan efisiensi penggunaan bow serta kecermatan dalam memainkan gruping, hal ini harus disertai dengan intonasi nada yang baik dan jelas.
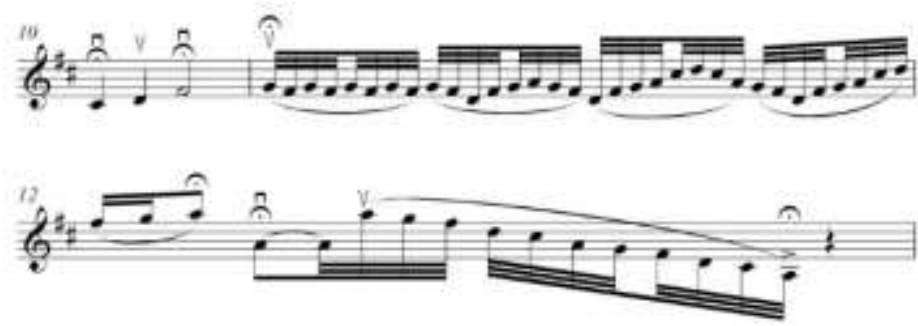

Notasi 2: Solo Biola pada Voorspell lagu Keroncong Senyuman Candra Bagian Kedua

permainan D descending (turun) dimulai dari nada A1 menuju A contra dengan menghindari nada E dan B. Pada nada A contra diberi permainan aksen sehingga memperjelas akhir pada Voorspell bagian ketiga.

sepertigapuluh dua ketukan ketiga dimainkan dalam posisi tiga kemudian untuk menjangkau nada E2 menggunakan jari empat dalam posisi empat, nada E2 dimainkan dengan aksen yang jelas dan tidak terlalu panjang. 


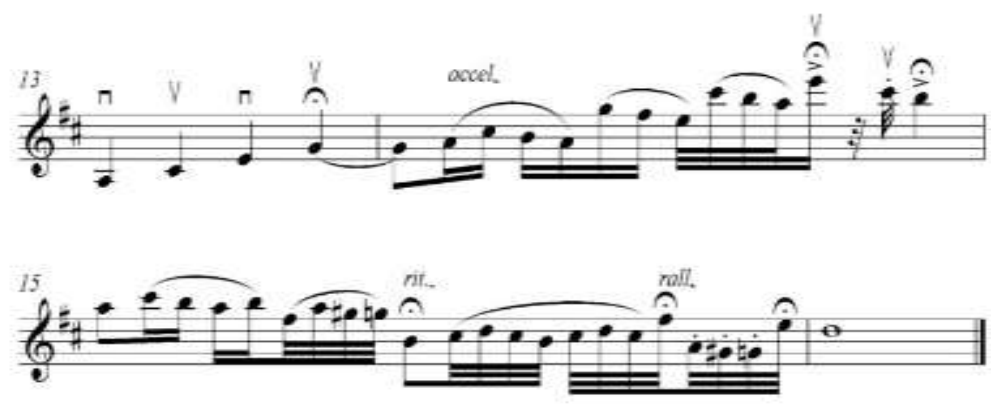

Notasi 3: Voorspell biola pada lagu Keroncong Senyuman Candra bagian ketiga

Pada birama lima belas dalam memainkan nada A1 sudah pada posisi tiga atau dengan jari satu, dan pada motif sepertigapuluh dua pada ketukan kedua sudah kembali pada posisi satu, kemudian dilanjutkan permainan gaya cengkok yang tertulis di atas dengan memperlambat tempo. Terdapat beberapa nada yang diperpanjang, nada yang diperpanjang merupakan nada pokok pada permainan birama lima belas, dan pada nada kromatis dimainkan dengan pendek namun jelas.

Pada bagian pertama dan kedua pada voorspell dalam lagu keroncong Senyuman Candra mengacu pada modus pentatonis yang menyerupai pelog pada gamelan Jawa, sehingga permainannya menghindari beberapa nada, hal ini sangat berbeda bila dibandingkan dengan voorspell pada umumnya yang mengacu pada akor I dan $\mathrm{V}$ dalam tangga nada diatonis.

Perbedaan yang cukup jelas juga terdapat pada sisipan permainan unisound oleh pemain belakang, hal ini juga tidak biasa dalam permainan voorspell memberi kejutan yang menarik dan inovatif bagi pendengarnya. Sisipan yang dimasukan dalam voorspell ini terasa sangat padu dan membentuk dialog musikal yang baik antara permainan biola dan pemain belakang unik.

Teknik permainan biola voorspell biola pada lagu Keroncong Senyuman Candra sebenarnya tidaklah jauh berbeda dengan memainkan karya-karya klasik untuk biola pada umumnya, teknik yang perlu dikuasai tentu teknik- teknik tangga nada, legato stacatto, variasi gruping, perpindahan posisi dan arpeggio atau tri suara. Permainan voorspell biola pada lagu Senyuman Candra juga sangat sarat dengan nada-nada pentatonis, sehingga membutuhkan pemahaman tentang variasi nada pentatonis, serta cermat dan teliti tentang nada apa saja yang boleh dibunyikan dan nada apa saja yang tidak boleh dibunyikan.

Pemain biola bukan hanya dituntut bermain dengan benar dan baik saja, tetapi dalam musik keroncong pemain biola juga dituntut memainkan melodi dengan istilah 'ngroncongi'. Hal ini merupakan yang paling sulit dalam penguasaan permainan, karena bukan hanya mencakup soal teknik saja, akan tetapi juga berkaitan dengan cita rasa.

Untuk dapat mencapai tahapan bermain dengan 'ngroncongi' pemain biola harus 
paham betul apa saja teknik biola yang diadaptasi dari teknik vokal keroncong, karena hal itu menjadi kunci gaya permainan akan terdengar 'ngroncongi' atau tidak. Pemain biola diharuskan memahami teknik-teknik dalam vokal keroncong seperti, cengkok, gregel, embat, mbesut, dan nggandul.

Pemahaman teknik-teknik berikut harus disertai dengan penerapan atau implementasi secara langsung, sehingga membutuhkan latihan khusus untuk melatih teknik-teknik tersebut dan juga menentukan kapan teknikteknik tersebut akan digunakan dan pada bagian mana saja, hal ini membutuhkan ketrampilan dan kecermatan dalam menentukannya.

Dalam hal penguasaan teknik juga membutuhkan teknik gesekan biola atau bowing yang baik, hal ini untuk menunjang permainan sehingga dapat menghasilkan warna suara atau tone colour yang baik. Pemain biola juga membutuhkan pengalaman langsung mendengar atau bahkan bermain bersama formasi keroncong lengkap, karena dengan begitu kita dapat melatih secara teknis maupun berlatih dalam hal gaya permainan, dengan adanya instrumen pemain belakang, insting bermain atau feeling bermain akan terasah dengan baik dan dapat diimplementasikan dengan lebih cepat.

\section{Simpulan}

Voorspell biola pada lagu Keroncong Senyuman Candra memiliki perbedaan dengan voorspell pada umumnya. Ini dikarenakan permainan voorspell memasukkan unsur modus pentatonis ke dalam voorspel bagian pertama dan kedua. Ini sangatlah mencolok dan asing dalam khasanah musik keroncong khususnya permainan voorspell. Voorspell pada umumnya mengacu pada akor dominan septim dan banyak menggunakan variasi arpeggio, akan tetapi pada voorspell pada lagu keroncong Senyuman Candra bagian pertama dan kedua tidak mengacu pada unsur akor dominan septim.

Dibutuhkan penguasaan teknik untuk memainkan voorspell keroncong. Hal lain yang dibutuhkan pemain biola yaitu pengetahuan bentuk dan kaidah-kaidah dalam voorspell pada lagu keroncong asli serta memahami dan menyelaraskan permainan voorspell dengan pemain belakang dalam hal ini memerlukan koordinasi dan kesepakatan, sehingga permainan voorspell dapat disajikan dengan rapi dan kompak.

\section{Daftar Pustaka}

Budiman, B. J. (1979). Mengenal Keroncong dari dekat. Jakarta: Perpustakaan Akademi Musik LPKJ.

Ganap, V. (2011). Krontjong Toegoe. BP iSi Yogyakarta.

Harmunah. (1987). Musike keroncong: sejarah, gaya, dan perkembangan. Pusat Musik Liturgi.

Kusbini. (1976). Sejarah Kebidupan Perkembangan dan Asal Usul Musik Kerontjong Indonesia. Sanggar Olah Seni Indonesia.

Soeharto, A. H., \& Soenardi, A. (1995). Serbaserbi keroncong. Penerbit Muzika. 
Syaodih Sukmadinata, N. (2017). Metode Penelitian Pendidikan. In Bandung: Remaja Rosda Karya. PT Remaja Rosdakarya.

Watanabe, R. T. (1967). Introduction To Music Research. Prentice-Hall, Inc.

Widjajadi, R. A. (2007). Mendayung di Antara Tradisi dan Modernitas (Sebuab Penjelajahan Ekspresi Budaya Terbadap Musik Keroncong). Hanggar Kreator. 